\title{
Environmental justice and its geographical aspects in Hungary
}

\author{
A környezeti igazságosság és földrajzi aspektusai \\ Magyarországon
}

\author{
GYULA NAGY
}

Gyula NAGY: assistant professor, Department of Economic and Social Geography, University of Szeged; Egyetem u. 2., H-6722 Szeged, Hungary; gynagy@geo.u-szeged.hu; https://orcid.org/0000-0001-7292-6513

KEYWORDS: inequality; marginalization; climate change; climate justice; theory of justice

ABSTRACT: In recent decades, environmental justice has become a defining concept in socio-spatial inequality research, political debates, and activism. Environmental justice research, which is essentially based on theories of social and spatial justice and provides a normative framework for thinking, focuses on the unequal distribution of environmental harms and risks and their social consequences. Environmental justice research aims to explore the economic, social, health, and legal differences that individuals and groups face in their environment as a result of environmental processes, decision making, power relations, and law enforcement practices. This is largely related to the subjective perception of individuals and the perception of injustices by different actors. In the vast majority of environmental justice studies, spatiality provides a framework for interpreting and understanding environmentally unjust situations and processes. Environmental justice is therefore not only a natural, but also a socially dependent phenomenon, in which the key element is nevertheless the non-human factor (e.g. environmental events such as floods), which affects individuals and groups in different ways. As a result, an environmentally unjust state and situation may occur. The evolved injustices also interact with inherited spatial inequalities, existing socioeconomic systems, and the institutional structures that originally shape them.

This paper summarizes the theoretical framework of environmental justice in geography and spatial sciences. The study adapts the theory of justice to post-socialist and Hungarian specificities and forms of environmental injustice, and examines decision-making processes and the perception of risks. In Hungary social problems and differences have been increasing in recent decades, and marginalisation and polarisation processes have added new spatial patterns to existing inequalities, directly and indirectly affecting environmental processes as well. Attempts at eliminating environmental injustices have resulted in new injustices, or deepened existing ones, due to the lack of a complex socio-environmental spatial approach of interventions. The solution to these injustices presupposes the effective and meaningful involvement of the affected people in policy-making and implementation processes, regardless of gender, age, origin, identity, or income. Otherwise, the unjust situation will persist and crisis areas affected by environmental injustices may develop.

NAGY Gyula: egyetemi adjunktus, Szegedi Tudományegyetem, Gazdaság-és Társadalomföldrajz Tanszék; 6722 Szeged, Egyetem u. 2.; gynagy@geo.u-szeged.hu; https://orcid.org/0000-0001-7292-6513

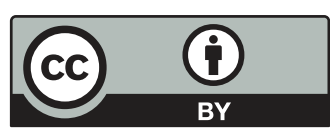


KULCSSZAVAK: egyenlőtlenség; marginalizáció; klímaváltozás; klímaigazságosság; igazságosság

ABSZTRAKT: Az elmúlt évtizedekben a környezeti igazságosság meghatározó gondolati keretté vált a társadalmi-és térbeliigazságosság-kutatásokban, politikai vitákban és aktivizmusban. A normatív gondolkodási keretet biztositó környezetiigazságosság-kutatások az igazságosságelméleten és a térbeli igazságosság alapjain nyugszanak. A kutatások fókuszában a környezeti ártalmak és kockázatok egyenlötlen térbeli elosztása és azok társadalmi következményei állnak. A környezetiigazságosság- kutatások azokat a gazdasági, társadalmi, egészségügyi és jogi különbségeket vizsgálják, melyekkel az egyének és különböző társadalmi csoportok a környezetükben zajló folyamatok, döntések, hatalmi viszonyok ésjoggyakorlatok következtében szembesülnek. Mindez nagyon eröteljesen kapcsolódik az egyének, a különbözo” szereplök szubjektív érzékelési és értékelési folyamataihoz. A környezetiigazságosság-kutatásokban jellemzően a térbeliség biztosítja az értelmezési keretrendszert a környezetben zajló igazságtalan folyamatok megértéséhez, így erösen kapcsolódnak a földrajzhoz, a tértudományokhoz. A környezeti igazságosság nem csupán természeti, hanem egyúttal társadalmi kérdés is, hiszen az embertöl független vagy csak részben függö környezeti tényezók (például egy árvíz) alapvetöen különböző módon érintik az egyének és csoportok mindennapjait, életét, s ennek eredményeként környezeti igazságtalanságok keletkeznek. Mindez szervesen kapcsolódik az átöröklött hatalmi és az aktuális társadalmi-gazdasági struktúrákhoz, melyek formálják a kialakult igazságtalanságokat.

A tanulmány alapjául szolgáló kutatás az igazságosság, a döntéshozatali mechanizmusok és a kockázatok érzékelése szempontjából vizsgálta a környezeti igazságosságok különböző megjelenési formáit. Magyarországon az elmúlt évtizedekben a marginalizáció és polarizáció folyamatai olyan új térbeli mintákat hoztak létre, amelyek hatnak a környezeti folyamatokra is. A tanulmány az igazságosságelmélethez kapcsolódva, esettanulmányokon keresztül mutatja be a posztszocialista közép-kelet-európai, illetve magyarországi viszonyok között jelentkezö környezeti igazságtalanságokat. A tapasztalatok rávilágítanak arra, hogy a környezeti igazságtalanságok felszámolására tett kísérletek gyakran újabb igazságtalanságokat eredményeztek, vagy elmélyítették a már meglévóket, mivel a beavatkozások során nem komplex térbeli, társadalmi és környezeti megközelitéssel kezelték a problémákat. Az igazságtalanságok megoldása, nemre, korra, származásra, identitásra vagy jövedelemre való tekintet nélkül, feltételezi az érintett személyek és csoportok bevonását a környezettel kapcsolatos döntésekbe. Amennyiben ez nem valósul meg, az igazságtalan helyzet fennmarad, és környezeti igazságtalanságokkal érintett válságtérségek jöhetnek létre.

\section{Introduction}

Much has been done to define the terms environmental justice and environmental injustice, but several questions remain. Following the rise of the human rights movements in the United States, the late eighties witnessed a plethora of research published on the topic of environmental justice. They also gave rise to the Environmental Justice Movement as a new pathway of human rights activism, which in many cases resulted in demonstrations against occurring injustices. Shortly after these demonstrations, the executive power responded in 1994, when President Clinton signed the Executive Order for Federal Actions to Address Environmental Justice in Minority Populations and Low-Income Populations (Faber, McCarthy 2001; Newton 2009).

Environmental justice is defined as a common right to a liveable and healthy environment which is sustainable and will be available for our children and 
grandchildren as well. No one should bear a disproportionate share of the negative environmental consequences resulting from industrial, governmental, municipal and commercial operations or policies (EPA 2021). Any government or public agency should try to reduce risks, especially for the most vulnerable groups who are usually more exposed to environmental injustices and less resilient (Pirisi 2019). Environmental injustice evolves when there is a lack of environmental justice, and its forms can vary from air pollution, inequities in waste management (Davies 2006; Higgs, Langford 2009), and inequities in industrial production (Boone et al. 2014; Oskarsson, Bedi 2018) to disaster-caused (Walker et al. 2006) inequity, like floods or landslides (Morar et al. 2021). Amidst several concepts and theories related to environmental justice, a pronounced difference between European and American approaches can be identified regarding the people who suffer the burdens of environmental injustices: ethnic or socioeconomic minorities. In the early 1990s, the American approach was largely concerned with injustices caused by racial discrimination (Bullard 1990, 1994; Cutter 1995; Hamilton 1995; Mohai, Bryant 1992), while European researchers stressed the importance of socio-economic status and multiple deprivations, in the evolution of environmental inequities (Braubach 2011; Braubach, Fairburn 2011; Cutter 2006; Laurent 2011; Walker 2012). Furthermore, the Environmental Justice Movement in the USA evolved from grass-root movements, whereas in Europe it was adapted as 'a response to the Aarhus Convention' (Boone et al. 2014; Mitchel, Norman 2012).

Despite the differences, both approaches agree that the consequences of injustices affect different social groups in different ways, putting some groups at an advantage and others at a disadvantage. All things considered, racial discrimination and deprivation can be important sources of injustice, hence socially, economically, and environmentally challenged people, such as lowincome, minority and ethnic groups, and/ deprived people must burden more of the environmental and social nuisances (Faber, McCarthy 2001; Filčák 2007; Newton 2009; Okereke 2006; Soja 2010).

These complex challenges can be answered through proper adaptation, which, however, depends on local and global power relations, decision-making mechanisms, legal processes, and practices. Unjust practices appear in everyday economic and political decisions and also in the legislature as procedural injustice (Cutter 1995; Walker 2012; Williams 1999). As spatial patterns of environmental injustice derive from social, economic, and political processes, the understanding of the economic and socio-cultural narrative of injustices bears great significance (Agyeman 2005). Environmental problems can be interpreted differently in various social contexts (Chukwumerije 2010).

Furthermore, common to both approaches is that processes in the environment are interpreted as the combined effect of human-environment relationships. These human-environment systems are in a state of constant 
transformation and change, and disturbances caused by the systems will result in inequalities and injustices with strong spatial consequences (Davidson, Anderton 2000; Pelletier 2010). Environmental injustices are space and scale-based as injustices appear differently in space and at various scales (Kurtz 2003) due to distributive processes (Walker 2012). Complexity is an inherent property of injustice, particularly in cases when the different parties involved view and understand the unjust situation differently. Complexity also derives from the recognition of the unjust situation, which is partly defined by geographical distance and proximity factors (Agyeman, Ogneva-Himmelberger 2009). It is particularly important that the growing human influence on environmental systems generates complex cross-scale problems that are not only locally observed, but also accompanied by various political, legal, social, and economic consequences. The success of adaptation depends on decision-making mechanisms, and various personal or social factors, such as values and norms, principles, rules, and individual and social knowledge (Gorddard et al. 2016).

Environmental justice is also considered to be a tool for reaching sustainability (Okereke 2006), provided that principles of fair treatment and inter- and intra-generational justice (Rawls 1971) are adopted and people collectively accept the norms of cooperation (Sachs 2008).

Consequently, during the early nineties, an ever-growing literature started to reveal environmental injustices in Western Europe as well. Despite this body of research conducted and published on environmental justice and injustice, relevant literature about Central and Eastern European (CEE) countries - apart from some examples (Boros, Nagy 2014; Filčák 2007; Harper, Steger, Filčák 2009; Málovics 2012; Nagy, Papp, Miklós 2017; Steger 2007; Varga, Kiss, Ember 2002) - is still severely lacking. This prompts questions about the ways researchers can apply theories of environmental justice to the CEE region whose socio-economic development has historically taken different pathways.

Socio-economic processes inherited from the former state socialist regime, effects of the transition to a neoliberal market economy, the reversion to political conservativism, increasing climate stress, and the changing human-environment relationship have caused environmental injustices in Hungary, which have not yet been addressed by research. This paper aims to fill this gap by developing a new understanding of the environment-human relationship from both a social and an individual perspective, and highlighting evidence of environmental injustices to help decision-makers make appropriate strategic interventions. The paper has three main questions. The first question has an exploratory nature in order to understand the situation of the CEE region and Hungary: What are the concerns, basic factors and starting points of the examination of environmental justice in the Hungarian and Central and Eastern European post-socialist setting? The second question is theoretical and it focuses on the different elements of the definition of environmental justice: What are the theoretical framework and its 
elements for examining environmental justice and injustice in Hungary? The third question focuses on the measurable evidence of environmental injustices: Are there more exposed areas for environmental injustice in Hungary? If yes, what evidence can be enlisted for environmentally unjust situations? This section makes an attempt to apply theories of environmental (in)justice to environmentally unjust processes in Hungary.

\section{Conditions of environmental justice in post-socialist Hungary}

The transition from state socialism to market economy in the former socialist countries can be considered as a very turbulent era from an institutional, legal and regulatory point of view. The transformation was influenced by inherited socialist structures, but also by the reigning political regimes at the time. Environmental injustice in Hungary and other post-socialist countries is rooted in the former socialist system as well as in processes during the transition period.

In the 20th century, the socialist regime's environmentally insurgent approaches (Hajdú 2006) strengthened the often negative anthropogenic influences on the environment in Hungary and other socialist countries. During the socialist era, the goal of socialist planning was the exploitation of nature and the economic use of resources and the environment (Fodor 1987). Environmental interventions were technocratic, mainly to mitigate the damage already caused, and the elimination of pollution was not an objective (Rabóczky, Pomázi, Zsikla 1990). There was no need for assessment of environmental damage and its short-term consequences. Therefore, there was no codified environmental law in the state socialist region (Prugberger 2001), since it was a second-rate and neglected aspect.

The pace and intensity of economic and political change took different pathways in these CEE countries: while in some, little or no substantial transformation took place, dynamic restructuring led to a dramatic increase in spatial inequalities elsewhere. Socio-economic transition has exposed a significant proportion of the population, economic actors, and administrative institutions to several challenges in Hungary. The transition from a state socialist economy to neoliberal capitalism significantly increased the poverty rate and the marginalization of certain social (often minority) groups, resulting in social polarisation (Pál, Boros 2010). This process has also been associated with the peripheralization of regions (Enyedi 1996, 2004; Szoboszlai 2006). The ever-increasing social and income gap between the poor and rich is continuing to grow in the country as well as in the CEE region (Kolosi, Keller 2010; Nagy et al. 2015). Significant territorial inequalities in which the urban-rural dichotomy plays a key role can be detected at the national and regional levels (Alpek B., Tésits 2020; Gyuris 2017; Máté, Pirisi, Trócsányi 2017; Pál et al. 2021). Geographical location plays a primary role in other inequalities as well, such as health status 
(Uzzoli et al. 2020), which affects the wellbeing of the people. Permanent crisis areas have emerged due to the transition, these spatial patterns became fixed by the economic crisis of 2008 (Váradi 2014), and the situation has been worsened by the recent global COVID-19 pandemic in Hungary, which is disconnecting these areas from global economic flows even more. Peripheries less developed rural areas - where unemployment has increased and tourismrelated incomes, visits, and overnights have decreased (Boros, Dudás, Kovalcsik 2020; Hajdú, Rácz 2020), have also suffered from the absence of general public and private services (Kovács et al. 2020).

Changing public and state roles during the transition have been linked to debates about justice. The state that shapes institutional systems and partly discourses, is also responsible for creating social injustice and spatial inequalities. The state also influences responses to environmental challenges by articulating or disregarding social and environmental problems. Environmental justice is thus not only a question of equal distribution of environmental risks and negative externalities, but it also concerns balances of power, since compensation can be identified as an act of power, and as a result of a decisionmaking mechanism (Begg 2018). An environmentally unjust situation can be justified by the state through a selective or only partially-enforced and guaranteed right to a healthy environment (Prugberger 2001). Such selective enforcement adheres to principles of profit maximization and cost minimization, and as a result, environmentally damaging activities will be relocated to areas with less advocacy and regulation, causing cumulative exposure for the inhabitants (Boros 2010) of post-socialist countries or regions. In some cases, environmental injustices and risks are eliminated or distributed relatively evenly with maximum compensation, while in other regions the unjust situation is preserved or exacerbated. These processes are intensified by the effects of global climate change to which different social groups, economic and political actors at various geographic scales have given different responses over the last decades.

As a result of climate change and lasting effects of the transition, the relationship between the environment and society is changing in the former socialist countries. The opportunity to develop a comprehensive environmental policy was forfeited in the years following the regime change due to neoliberal economic policies (Agyeman, Ogneva-Himmelberger 2009). This changed the expectations and priorities of the population concerning their environment, as well as their willingness to take environmental risks. Due to climate change, and the increased magnitude and frequency of weather extremities such as irregular precipitation, drought is causing increasing environmental risks and dangers to the Hungarian population. Climate change impacts have been exacerbated by neoliberal and neoconservative environmental protection practices on the one hand and biased environment protection policies of the neoliberal and neoconservative governments, on the other. As research on environmental justice 
has pointed out, inadequate regulations thus might become causes of emerging injustices. Although environmental processes are not discriminatory per se and they do not affect individuals based on income or ethnicity, changes in the environment might still generate unfair impact in social terms.

Environmental processes thus might become starting points or accelerants of socio-economic polarization and marginalization, and the evolution of environmental injustices. At the same time in the CEE region legal, constitutional, and democratic deficits also contribute to the evolution of environmental injustices. The theoretical framework that was adopted to highlight these processes is presented in the next chapter.

\section{The theoretical framework applied to measure environmental justice in Hungary}

The concept of environmental justice comprises more than simply 'environment' and 'justice'. It can be described along five major components: environment (1), the concept of justice (2), the process of the evolution of injustice (3), evidence of injustice (4), and scale (5) that constitute a theoretical framework of environmental justice (Fig. 1).

Figure 1: Theoretical framework of environmental justice A környezeti igazságosság elméleti kerete

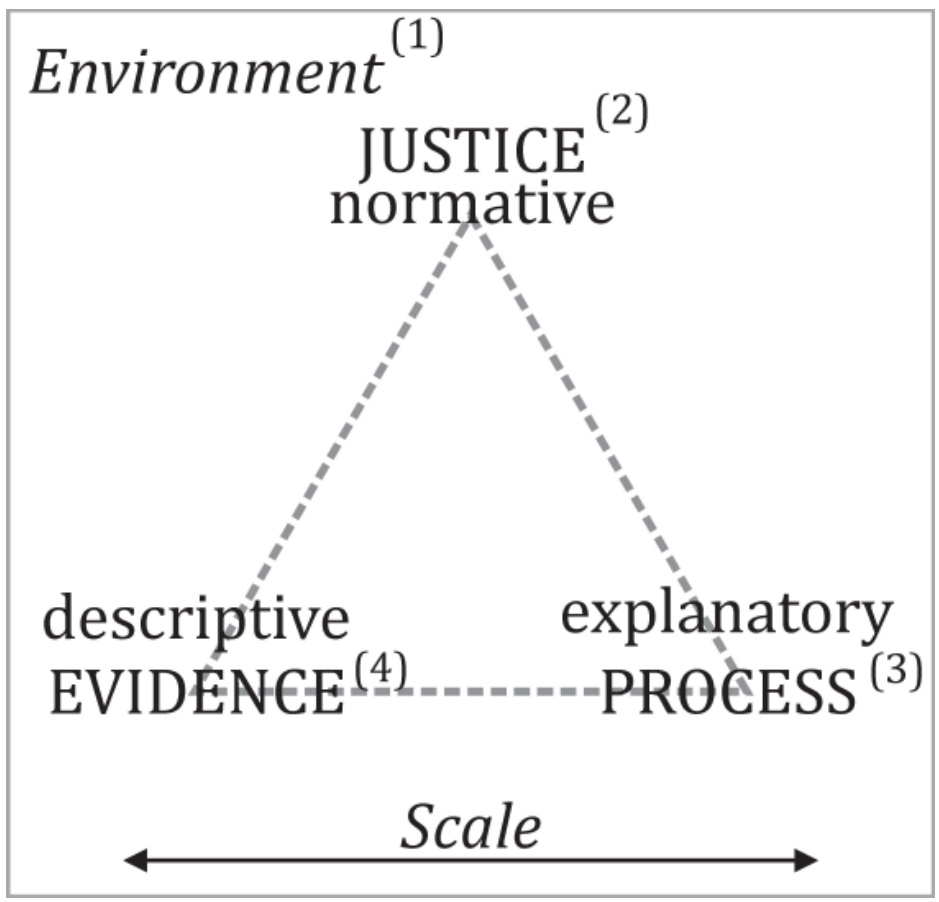

Source: the author, adopted from Walker G. 2012 
The concept of the environment (1) is multifactoral, including the tangible world around us, i.e. the built and natural environment, and the associated intangible world, i.e. the mental environment of a person or a group, a community, and multiple socioeconomic and political relations among different actors (Eden 2009). Inequalities are connected to unequal exploitation of the natural environment and limited access to a quality environment. These are not triggered by the finiteness of the natural environment, but by technological and justice deficits within society that are unable to exploit resources properly and provide benefits equally for all. Environmental risks derived from various causes provide a starting-point for the evolution of environmental injustices. This research examines spatial structures and landscape features of environmental damage and degradation caused by climate change or a post-socialist heritage of insurgent environmental and development policy. Since the positional or relational distribution of environmental risks (Curran 2013) are causing a significant subset of environmental inequalities it is important to research them. Areas facing environmental hazards and risks must be delimited to draw attention to potential places of the formation of environmental injustices and, later, to eliminate them by identifying their causes.

The concept of justice (2) is a normative concept consisting of three main components: distribution (2a), perception (2b), and procedure (2c) (Walker 2012). The term justice and its meaning are defined by the community through a social contract (Steiger 1997). The emphasis of environmental justice research has shifted from the former single focus on the distribution of injustice to exploring processes that lead to injustice (procedural justice) and to the individual's perception comprising multiple and subjective evaluations of the concept of truth (recognitional justice) (Walker 2012). Environmental injustices are often embedded in natural, environmental processes, but are also related to the actions and reactions of human agents. Differences in socio-economic status, the regional or local availability of resources, and the individual's original position influence the above-mentioned actions and reactions. Perceptions of the inequalities connected to the distribution of environmental risks and hazards sometimes inhibit people and groups from understanding the processes behind environmental injustices. This can decrease the perceived risks but intensify the real risks for the least advantaged (Curran 2013), meanwhile the extent of environmental injustice declines for those in a better, advantaged position through power.

The distribution of justice is process-dependent, and perceptions of the lack of justice per se are influenced by the sociocultural and income factors of the individual and the community (Bullard 1990; Špirić 2018). At the same time there can be claims for both justice and injustice related to these perceived environmental risks and inequalities. Since there is no adequate relationship between inequality and injustice (Walker 2012), individuals and groups 
may have different perceptions and attitudes about environmental injustice, from wholeheartedly supportive 'PIMBY' (Put in My BackYard) to wholly dismissive 'BANANA' (Build Absolutely Nothing Anywhere Near Anything/Anyone) (Gbanie et al. 2013). Not only individual, but also geographical attitudes can be distinct, so Locally Unwanted Land Use or Locally Wanted Land Use (LULU and LWLU) can evolve. This also raises the question of whether environmental inequalities are just or unjust. All of these attitudes may change over time due to external factors (such as an information campaign). Changes in attitudes may also be associated with a change in subjective values, or particular processes, of recognition of injustice (Been 1994; Kaya, Erol 2016). This leads to an uneven risk society (Curran 2018) instead of a universal one (Beck 1992). People and groups can perceive just and unjust situations at the same time, therefore environmental injustice should be examined along with the attitudes and opinion of different groups or individuals involved in injustices.

Processes leading to injustice can be examined in terms of decisions and time (3). On this basis, top-down and bottom-up decision-making can be distinguished (3a), and ex-ante and ex-post injustices by their time perspective (3b). During the socialist period, interventions in unjust situations were mostly top-down processes, which in many cases ignored everyday practices, habits, and local adaptation techniques. This can be particularly detrimental if the institutions are adopting and misinterpreting Rawls's original position theory (Rawls 1971). In the case of environmental injustices, especially in the case of disasters, the stakeholder groups use a specific decision-making mechanism (Cornell et al. 2013), since each actor has their values, knowledge, norms, and rules to act on (Gorddard et al. 2016). Conflict arises when the actors' decision-making and action mechanisms collide resulting inadequate reactions. Without adequate knowledge of the local context, decisionmaking will result in unjust or unfair procedures. To detect injustices, satisfaction with the information provided during and compensation provided after environmental unjust situations can be measured. This satisfaction rate somehow reflects partnership in the process of decision-making and the transparency of (re)distributed resources.

When uncovering environmental injustices in time, ex-ante and ex-post processes, coexisting with one another, are defined. Ex-ante injustice occurs when deeper and more complex socioeconomic processes and power relations are present in the background of an environmental event (such as a catastrophe). Ex-post injustice evolves when an environmental event triggers and accelerates environmental degradation and social deprivation, and creates a downward spiral process (Liao, Hui Chan, Huang 2019). In each case of proposed environmental injustice, a broader timeline of events must be unfolded to understand a bigger picture and the temporal nature of environmental injustices.

The intrinsic manifestation of evidence of injustice has a spatial pattern that can be measured both quantitatively and qualitatively (4) and can be observed at 
different scales. According to the literature, the most important of these are fear of perceived or actual risks, attitudes towards unjust situations, advocacy skills, compensation and aiding process, change in the settlement milieu, the objective and subjective health-status of individuals, changes in the social composition of the settlements, transformation of mobility patterns, and real estate market aspects. Environmental injustices occur in a multidimensional and multiscale geographic space, in which scales and different spatial units are constantly interacting (Walker 2012) (5). The appropriate choice of the scale for analysis is crucial (Fabula, Timár 2016), since the chosen areal unit - the applied scale - has a modifiable effect on the analysed data, which can lead to ecological misconceptions in several cases. This suffices a problem defined as a modifiable areal unit problem (MAUP) (Kovalcsik, Nzimande 2019; Maantay, Maroko 2009; Swift, Liu, Uber 2008).

Figure 2: Theoretical framework for measuring environmental injustices A környezeti igazságtalanságok feltárásának vizsgálati aspektusai

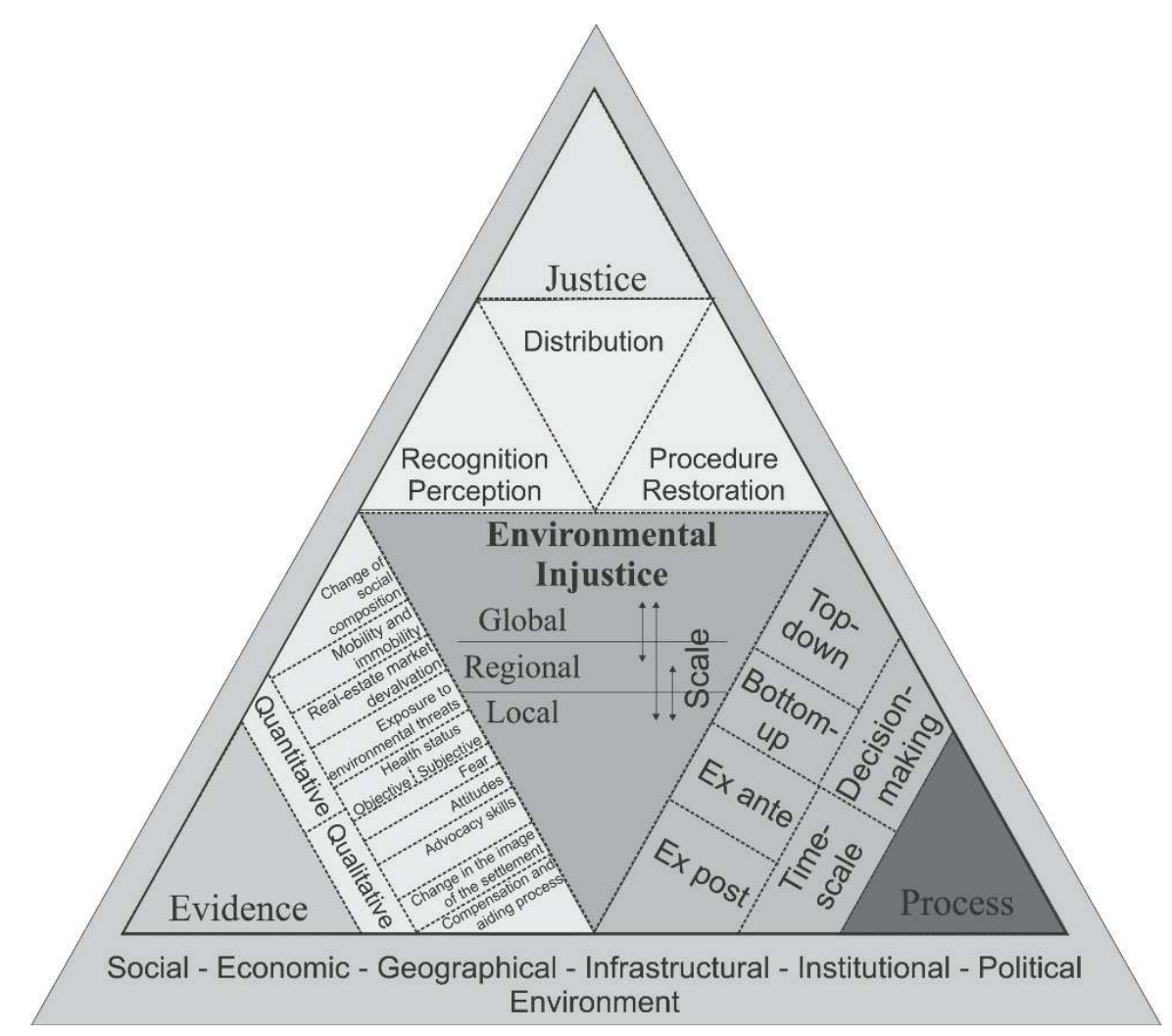

Source: the author, 2021

\section{Methods and study area}

Environmental justice studies are multi-scale and adopt several methodological approaches. In the initial period of environmental justice research, mainly quantitative methods were used to identify and measure injustices, while qualitative testing methods were adopted later. This study applies both points of view. 
In many cases, unjust and unfair situations cannot be demonstrated by objective indicators alone. Environmental justice studies, therefore, examine not only the evidence of injustice but also the processes that cause them and the perception of the injustice by those affected. In recent years, numerous studies and press reports have been published on floods, red mud spills, and problems caused by excess inland water in Hungary, which also reported the dissatisfaction of the population affected by these disasters. This paper describes the evidence and the manifestations of environmental injustices in the selected sample areas according to the five main components described above. To describe the evidence and manifestations based on WHO recommendations, a principal component analysis was used to identify presumed municipalities or areas affected by environmental injustices. Respectively, 16 compound indicators relying on data from 2010-2017 were used. Four analytical dimensions - the safety of the built environment, the natural-physical environment, the degree of

Table 1: Indicators used to delimit presumed areas of environmental injustices in Hungary A feltételezhetôen környezeti igazságtalansággal érintett települések lehatárolásához használt indikátorok

\begin{tabular}{|c|c|}
\hline Dimension & Indicator \\
\hline \multirow{4}{*}{$\begin{array}{l}\text { Safety of built } \\
\text { environment }\end{array}$} & Proportion of uncomforted and semi - comfort dwellings 2011(\%) \\
\hline & Number of crimes per 100 people 2011, 2013, 2015 (pieces) \\
\hline & Number of accidents per 1000 people 2011, 2013, 2015 (pieces) \\
\hline & Number of cancer patients per 1000 population, 2011, 2013, 2015 (persons) \\
\hline \multirow{4}{*}{$\begin{array}{l}\text { Natural- } \\
\text { physical } \\
\text { environment }\end{array}$} & Area affected by floods (dummy) 2010, 2013, 2015 \\
\hline & Area affected by inland water (dummy) 2010, 2013, 2015 \\
\hline & $\begin{array}{l}\text { Data on drinking water quality (ammonium, arsenic, boron) in excess of the limit } \\
\text { value in drinking water (\%) 2011,2013, } 2015\end{array}$ \\
\hline & Value of hazardous waste per capita 2011, 2013, $2015(\mathrm{~kg})$ \\
\hline \multirow{3}{*}{ Urbanity } & Resident population of the settlement - detection of dwarf and small village areas \\
\hline & Proportion (\%) of 0-14 year olds, juvenile structure \\
\hline & Aggregate institutional supply indicator 2011, 2013, 2015 \\
\hline \multirow{5}{*}{$\begin{array}{l}\text { Socio- } \\
\text { economic } \\
\text { environment }\end{array}$} & Consolidated personal income tax base per capita (HUF / person) 2011, 2013, 2015 \\
\hline & Proportion of Roma and Gypsy population (\%) 2011 \\
\hline & Proportion of graduates of up to eight classes of working age in 2011 (\%) \\
\hline & $\begin{array}{l}\text { Proportion of registered jobseekers within the total population (\%) worse than } \\
\text { the national average } 2011,2013,2015\end{array}$ \\
\hline & $\begin{array}{l}\text { Difference between the proportion of taxpayers belonging to the lowest and } \\
\text { highest tax categories, 2011, 2013, } 2015\end{array}$ \\
\hline
\end{tabular}


urbanity, and the socio-economic environment - were formed according to the principal component analysis (Table 1).

Longitudinal comparative analysis was performed (for the data of the years of 2011, 2013, 2015) along the 4 dimensions, and a composite indicator, 'exposure to environmental injustice', was calculated. Spatial autocorrelation was calculated using the Getis-Ord method. Spatial autocorrelation is a concept that helps to define hot and cold spots using the correlation of an observation with other observations through space (Abdulhafedh 2017). The spatial autocorrelation method helps spatial clustering to identify the 'best' and the 'worst' performing areas resulting from the analysis according to the examined indicators. The presence of positive spatial autocorrelation shows areas or sites that are close to one another and have a tendency to share similar values in all of the dimensions (Haining 2001). A composite map was created delimiting the areas potentially affected by environmental injustices. In this paper, three different types of potential areas of environmental injustices (flooding, inland water, and red mud disaster) in four sample areas (Fig. 3.) were examined.

As environmental injustices are the result of processes below the municipal level, a questionnaire and interview survey was made. MS Excel and SPSS22.0 were used to process results. Questionnaires were completed in the sample areas with the help of interviewers, and query methods were adapted to the specificities of the sample areas (Table 2). Statistical analysis was made on the

Figure 3: Sample areas of the research

A kutatás mintaterületei

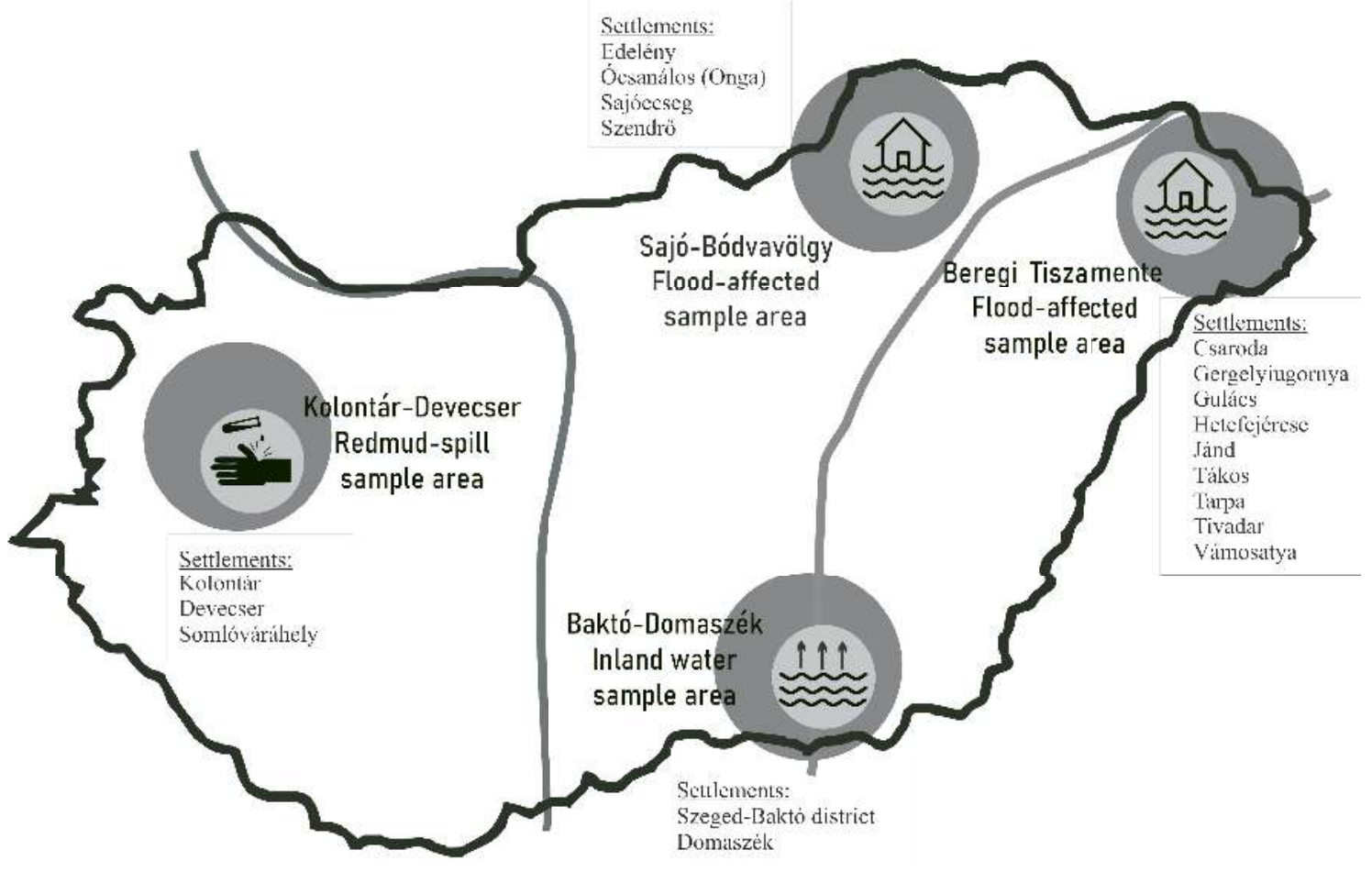

Source: the author, 2021 
result of the surveys, principal component analysis and cluster analysis was conducted, and decision trees were drawn (Nagy et al. 2019). In the case of the questionnaire data, a statistical correlation was measured and Chi-square tests were done. The difference and similarity of the metric data were revealed by using a paired t-test. To understand the compensation and the aiding process and to clarify the legal environment a legislative analysis was made. To reveal the power relations, the background of the renovation of the damaged settlements, published papers, online news, and journals on the topic were analysed. To interpret the context of injustices, government regulations and decisions were analysed. To supplement the results of the questionnaire, 10 semi-structured interviews were conducted, with 6 people in flood-affected sample areas, and 4 in sample areas affected by the red mud spill. Interview questions were related to the disaster and compensation process. In particular, they aimed to explore the extent and causes of the injustices that featured the settlements.

Table 2: Sampling method, date, and number of queried units of the sample areas A mintavétel jellemzői, dátum, mintavételi stratégia és kitöltött kérdöívek száma alapján

\begin{tabular}{lccr}
\hline \multicolumn{1}{c}{ Sample area } & $\begin{array}{c}\text { Number of } \\
\text { questionaries }\end{array}$ & Sampling method & Date of the survey \\
\hline $\begin{array}{l}\text { Beregi Tisza mente flood } \\
\text { affected sample area }\end{array}$ & 411 & Quoted sampling & 29.09-02.10.2011 \\
$\begin{array}{l}\text { Sajó-Bódvavölgy flood- } \\
\text { affected sample area }\end{array}$ & 443 & Quoted sampling & 20.10.-23.10.2011 \\
$\begin{array}{l}\text { Kolontár-Devecser red- } \\
\text { mud-spill affected sample }\end{array}$ & 147 & Randomized & 28.02-01.03.2014 \\
area & & systematic sampling & \\
$\begin{array}{l}\text { Baktó-Domaszék inland } \\
\text { water affected sample area }\end{array}$ & 243 & Randomized & 02.05-10.05.2015 \\
\hline \begin{tabular}{l} 
Total \\
\hline
\end{tabular} & 1,247 & systematic sampling & \\
\hline
\end{tabular}

Source: the author, 2021

\section{Examined aspects of environmental injustice, and spatial and social patterns in Hungary}

\section{Potential areas of environmental injustice}

To highlight the areas of Hungary which are presumably affected by environmental injustice, a composite map of spatial autocorrelation was used. The blue areas on the map represent the low-low clusters, and the red ones the high-high clusters. The results of the map overlap with those areas previous research defined as areas 
of social inequality and as underdeveloped regions of Hungary (Nagy 2006; Nagy, Boros 2015; Nagy et al. 2015; Pénzes, 2014; Pénzes, Tátrai, Pásztor 2018). These areas are characterized by lower socio-economic status (Fig. 4.), such as Northern Hungary, the former socialist energy axis of Ajka and Devecser and their microregion - known for its former alumina production and heavy industry -, South-Transdanubia - characterized by an unsuccessful sectoral transition -, and the Tisza-valley affected by inland excess water problems and floods.

Figure 4: Presumed areas for environmental injustices along four dimensions with a Getis-Ord hotspot analysis method A környezeti igazságtalanságokkal potenciálisan érintett területek lehatárolása a Getis-Ord módszerrel készült hotspot elemzés alapján

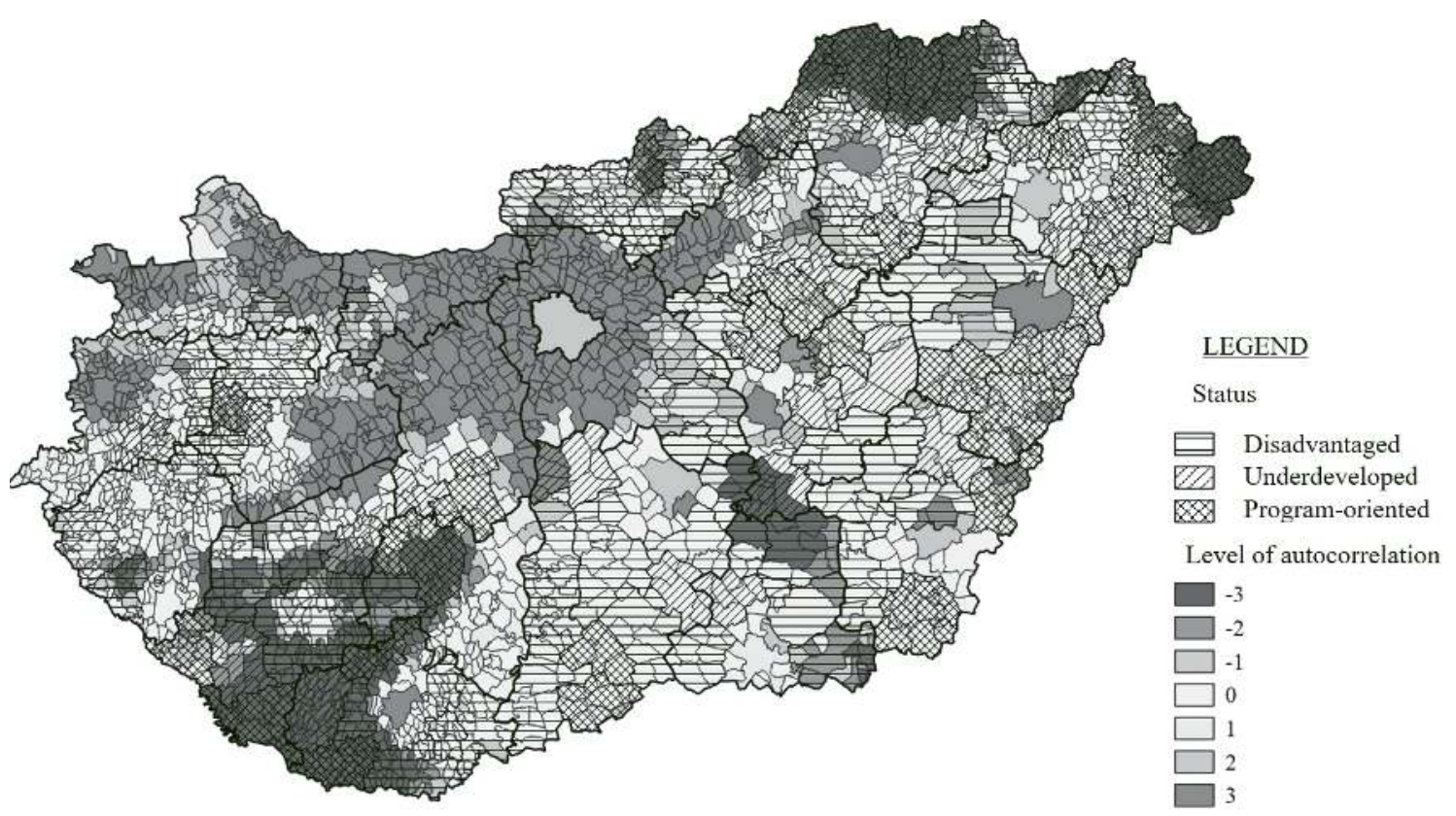

Source: from CSO data edited by the author, 2021

\section{Fear and change in the sample areas}

First, the aspects of fear and change were examined. In general, the population of disaster-affected areas fear a possible recurrence of the disaster and feel stress in their daily lives following the disaster. In order to study fear, a principal analysis related to fear was conducted using the statements ('I am worried for my and my family's health', 'My friends consider my place of living dangerous', 'It is more dangerous to live here than anywhere else' etc.). The result shows that in all study areas and examined cases, two groups can be separated: those who were affected and those who were not affected by the disaster. On this basis, it is generally confirmed that in all three types of study areas, those affected significantly confirm the indicator of principal component of fear, while those who have been indirectly affected by the disaster reject it. Reduction in fear is 
caused by lower levels of damage suffered, but this effect is less significant for disasters that take place over longer periods of time. The population can be primarily divided into directly and indirectly affected groups, and those affected by any disaster tend to confirm the principal component of fear. There is a significant statistical difference between the groups directly and indirectly affected by disasters in terms of fear (Table 3). The significant level of difference shows traces of racial environmental injustice; however, it is not the stereotypical injustice described in the early 1990s.Data indicate a divide along the lines of ethnicity; Roma people tend to feel more fear than the non-Roma population. This result implies that ethnic minority people suffer more from environmental injustices. However, it is also important to note that sample areas and their unique characteristics influence individual's degree of fear and recognition of change.

The change in the social composition of the examined municipalities is evidenced by the fact that more than $40 \%$ of respondents in all sample areas believe that the society of settlements has changed. However, there are large differences between the sample areas (Fig. 5). Nearly $80 \%$ of respondents of the sample who were affected by inland water feel that the social composition has not changed at all as a result of the disaster caused by inland excess water. In the case of settlements affected by floods and red mud spill, 50-65\% of the respondents perceived social composition changes.

The disastrous event and its effects on the urban fabric and the change of the social environment of the settlements were also examined. In all four sample areas, the majority of respondents reported a positive change in the settlement's image and milieu. However, there is a marked difference between the groups of municipalities in the case of flooded sample areas. Respectively, $60 \%$ of the respondents in the Sajó-Bódvavölgy sample area think that the settlement's image has changed in the wrong direction after the flooding. Those who received no or just little compensation tend to feel more negative changes in the settlement, than those who were aided or reimbursed (Table 4). This is linked to the compensation process which has been widely criticized with regard to its corruption and unjust practices.

All in all, it is the disaster-response strategy that significantly determines how each group perceives the recent situation and the future of the sample areas. The majority of the surveyed population in all four sample areas state that their living circumstances are similar or a little bit worse than before the disasters (Table 5). This suggests the presence of procedural injustice as well. 


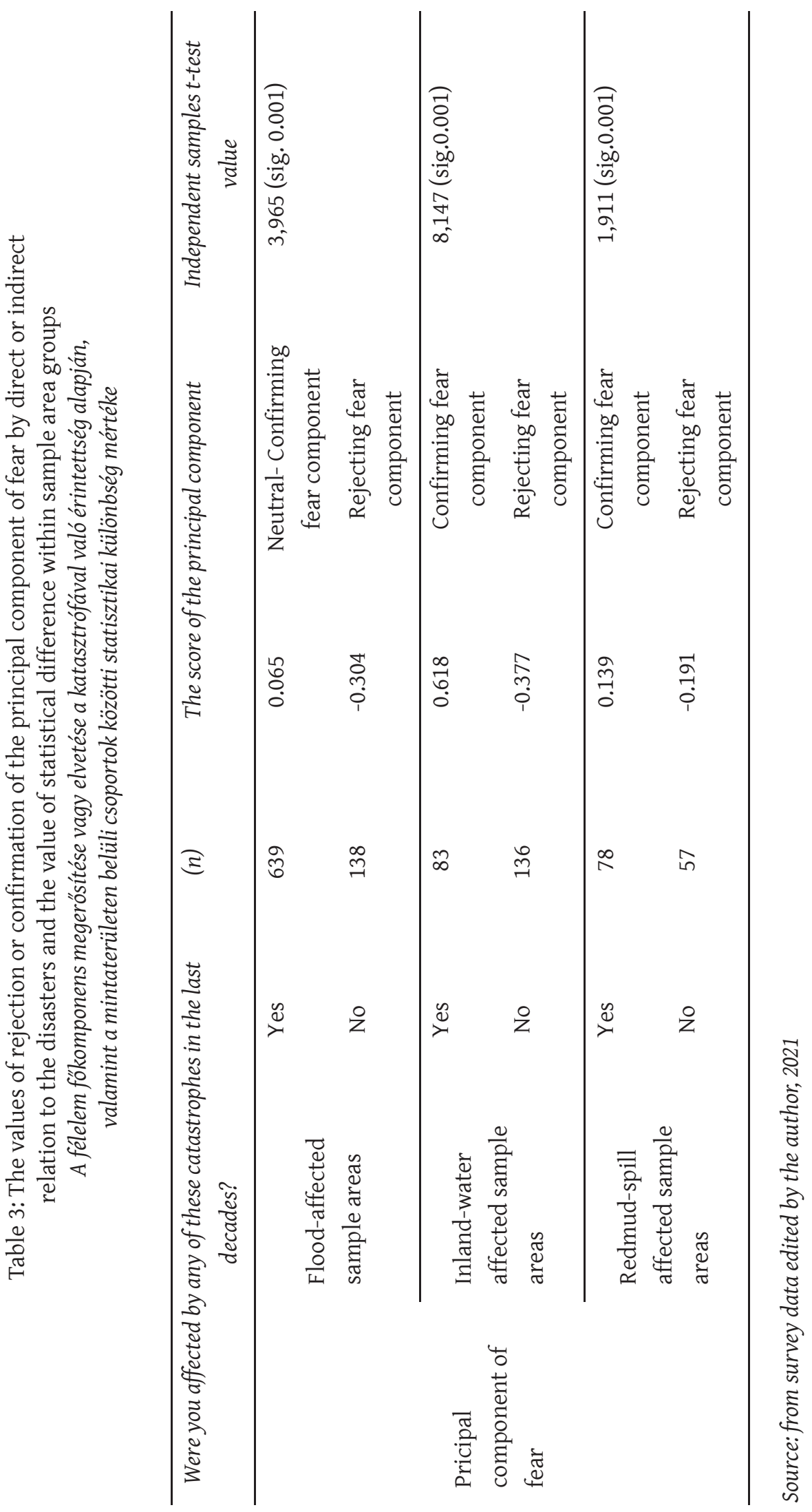


Figure 5: The principal component scores of change in the flooded sample areas A változás fókomponens értékei az árvizes mintaterület településein

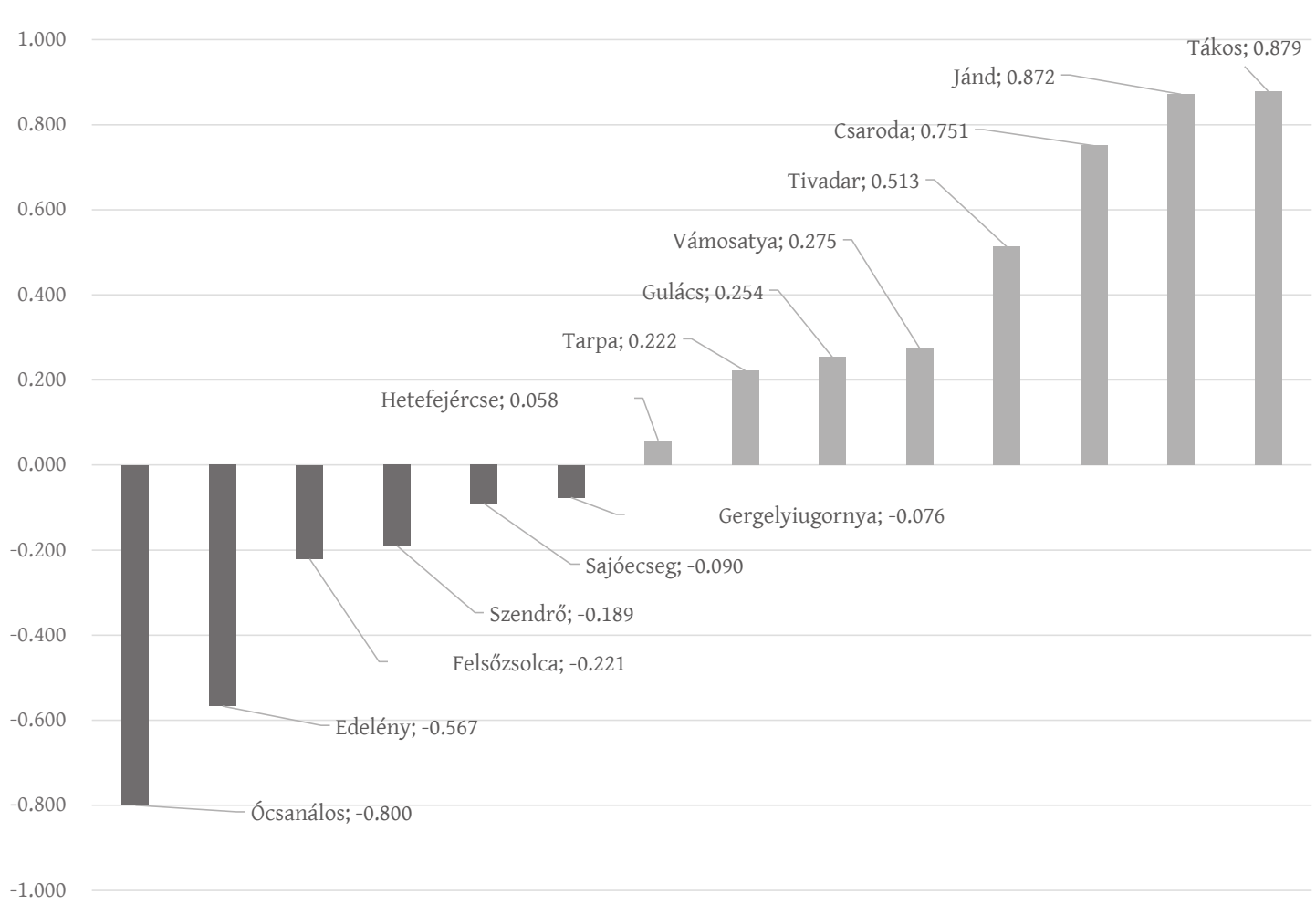

Source: from survey data edited by the author, 2021

Table 4: The values of rejection or confirmation of the principal component of change by direct or indirect relation to the disasters A változás fókomponensének elutasítása vagy megerösítésének értékei az érintettség függvényében

\begin{tabular}{|c|c|c|c|c|c|c|c|c|}
\hline \multicolumn{9}{|c|}{ Principle Component of Change } \\
\hline Sample area & \multicolumn{2}{|c|}{$\begin{array}{l}\text { Beregi Tisza mente } \\
\quad \text { flooded area }\end{array}$} & \multicolumn{2}{|c|}{$\begin{array}{l}\text { Sajó - Bódvavölgy } \\
\text { flooded area }\end{array}$} & \multicolumn{2}{|c|}{$\begin{array}{c}\text { Kolontár-Devecser } \\
\text { redmud-spill affected } \\
\text { sample area }\end{array}$} & \multicolumn{2}{|c|}{$\begin{array}{l}\text { Domaszék-Baktó } \\
\text { inland excess water } \\
\text { affected sample area }\end{array}$} \\
\hline $\begin{array}{l}\text { Directly } \\
\text { affected? }\end{array}$ & $\begin{array}{c}\text { General opinion } \\
\text { (component } \\
\text { value) }\end{array}$ & (n) & $\begin{array}{c}\text { General opinion } \\
\text { (component } \\
\text { value) }\end{array}$ & (n) & $\begin{array}{c}\text { General opinion } \\
\text { (component } \\
\text { value) }\end{array}$ & (n) & $\begin{array}{c}\text { General opinion } \\
\text { (component } \\
\text { value) }\end{array}$ & (n) \\
\hline Yes & $\begin{array}{c}\text { Positive } \\
\text { change }(0,34)\end{array}$ & 294 & $\begin{array}{l}\text { Negative } \\
\text { change } \\
(-0,38)\end{array}$ & 375 & $\begin{array}{c}\text { Positive } \\
\text { change }(0,27)\end{array}$ & 77 & $\begin{array}{c}\text { Positive } \\
\text { change }(0,71)\end{array}$ & 77 \\
\hline No & Neutral $(0,08)$ & 76 & $\begin{array}{c}\text { Positive } \\
\text { change }(0,12)\end{array}$ & 68 & $\begin{array}{l}\text { Negative } \\
\text { change } \\
(-0,33)\end{array}$ & 62 & $\begin{array}{l}\text { Negative } \\
\text { change } \\
(-0,45)\end{array}$ & 122 \\
\hline
\end{tabular}

Source: the author, based on survey data, 2021 
Table 5: Subjective assessment of life quality and living circumstances Az életkörülmények és életminőség szubjektiv értékelése

\begin{tabular}{ccccccc}
\hline \multicolumn{7}{c}{ Respondents (\%) } \\
\hline $\begin{array}{c}\text { Assessment of } \\
\text { living circums- } \\
\text { tances and life } \\
\text { quality }\end{array}$ & $\begin{array}{c}\text { Beregi Tisza } \\
\text { sampleflooded }\end{array}$ & $\begin{array}{c}\text { Sajó-Bódvavölgy } \\
\text { flooded sample } \\
\text { area }\end{array}$ & $\begin{array}{c}\text { Domaszék- } \\
\text { BaktóInland } \\
\text { water sample } \\
\text { area }\end{array}$ & $\begin{array}{c}\text { Kolontár-Devecser } \\
\text { Redmud-spill } \\
\text { affected sample } \\
\text { area }\end{array}$ & $\begin{array}{c}\text { Mean } \\
\text { Assessment of } \\
\text { living circums- } \\
\text { tances and life } \\
\text { quality }\end{array}$ \\
\hline $\begin{array}{c}\text { Much better } \\
\text { Better }\end{array}$ & 2.52 & 0.00 & 0.00 & 1.41 & 1.00 & Much better \\
Similar & 11.48 & 5.01 & 6.52 & 5.63 & 7.38 & Better \\
Worse & 45.94 & 52.85 & 77.17 & 57.75 & 56.75 & Similar \\
\hline
\end{tabular}

Source: the author, based on survey data, 2021

\section{Satisfaction and involvement in decision-making}

It is also important to see whether or not and how satisfied stakeholders are with the remediation process, the compensation they are provided with, and the information they receive during and after disasters. In general, top-down interventions and compensations seem to be more successful than bottom-up 'liberalized' ones, which were reported to be ridden with corruption and unfair practices. In both red mud-affected and flooded areas, the terms 'gold flood' and 'gold mud' were used to indicate the injustice of compensation. Some stakeholders profited from the disaster, while others received nothing. Some interviewees complained that it was difficult to get compensation: 'Not everyone gets compensation, if they do, it is only after years of litigation'. Others argued that compensations depended on local power relations: 'those close to power received more', and compensation is not equal: 'others received more for similar damage, there was insufficient information' and 'those affected were not properly compensated when houses were damaged'. This suggests an inadequate distribution of resources, which privileged some and disadvantaged others. At the same time, the dominant popular and political discourse suggests that disadvantaged people should be grateful and satisfied with the compensation they received because their houses are rebuilt in better quality than before. Some respondents thought the level of compensation was 'excessive', while others pointed out that 'some got a lot, some got nothing, compensation was disproportionate'. All in all, respondents were not fully satisfied with the interventions, given slow and dubious information flow, a lack of transparent procedures (Fig. 6). These situations can be regarded as examples of procedural environmental injustice. 
Figure 6: Satisfaction with state compensation process in the sampling areas (inland water areas did not receive state-led compensation)

A kompenzációval való elégedettség a kiválasztott mintaterületeken (a belvizes mintaterületeken nem járt kompenzáció)

Beregi Tisza mente flooded area
Sajó-Bódvavölgy flooded area
Kolontár-Devecser redmud-affected area

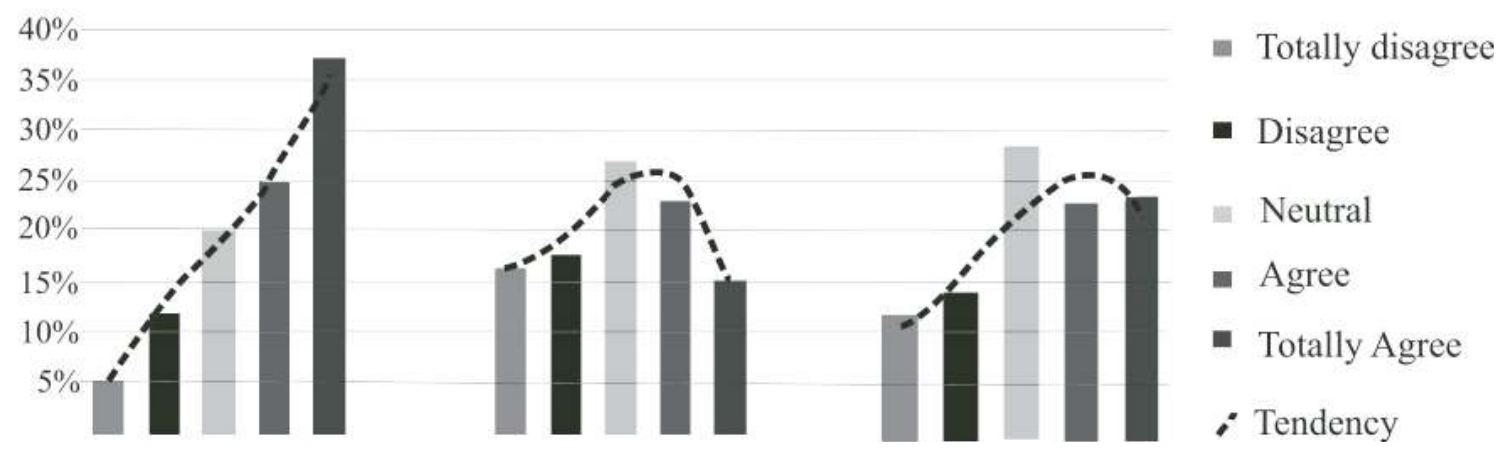

Source: from survey data edited by the author, 2021

\section{Spatial and social patterns of environmental event-led mobility}

Environmental injustice can influence the image of an area in the long run and hinder regional mobility. According to research results, a fast and visible differentiation and transformation started in the studied areas, which are reflected not only in the change of the real estate portfolio but also in the mobility of the population. Outmigration of the wealthy began after the disaster, which is generally identified as 'riskscape', i.e. the escape of the wealthy from risks. Nearby major cities and regional centres were considered as the main migration targets (Fig. 7), but in several cases, Budapest or its metropolitan area also appeared as an outmigration destination, as in the case of the beregi Tisza mente flooded sample area.

In addition to outmigration, a real estate market trap evolved in the affected areas. Real estate purchases did not reflect previous market prices: estates could either not be sold or only at a very low price. State intervention, which in many cases did not compensate the stakeholders equally, prevented outmigration from the area through legal constraints on selling renovated homes. Stakeholders' decision to remain in the settlements was often due to family or work commitments, or it was induced simply by habits. One-tenth of the interviewed stakeholders decided not to leave the disaster area in fear of not being able to find jobs elsewhere. Anxiety about job-market mobility was most pronounced in the red mud-affected sample area, where $69 \%$ of the population opposed to end alumina production, while $58 \%$ thought that their health was more important than a job. Our research indicated that those affected by healthdamaging activities generally wish to live in a healthy environment, but if it affects their existence, they accept or even support polluting activities. In the literature this is regarded as switching attitudes from the so-called BANANA to 
Figure 7: The major mobility destinations in the beregi Tisza mente flooded sample area Legföbb költözési irányok a Beregi Tisza mente mintaterületen

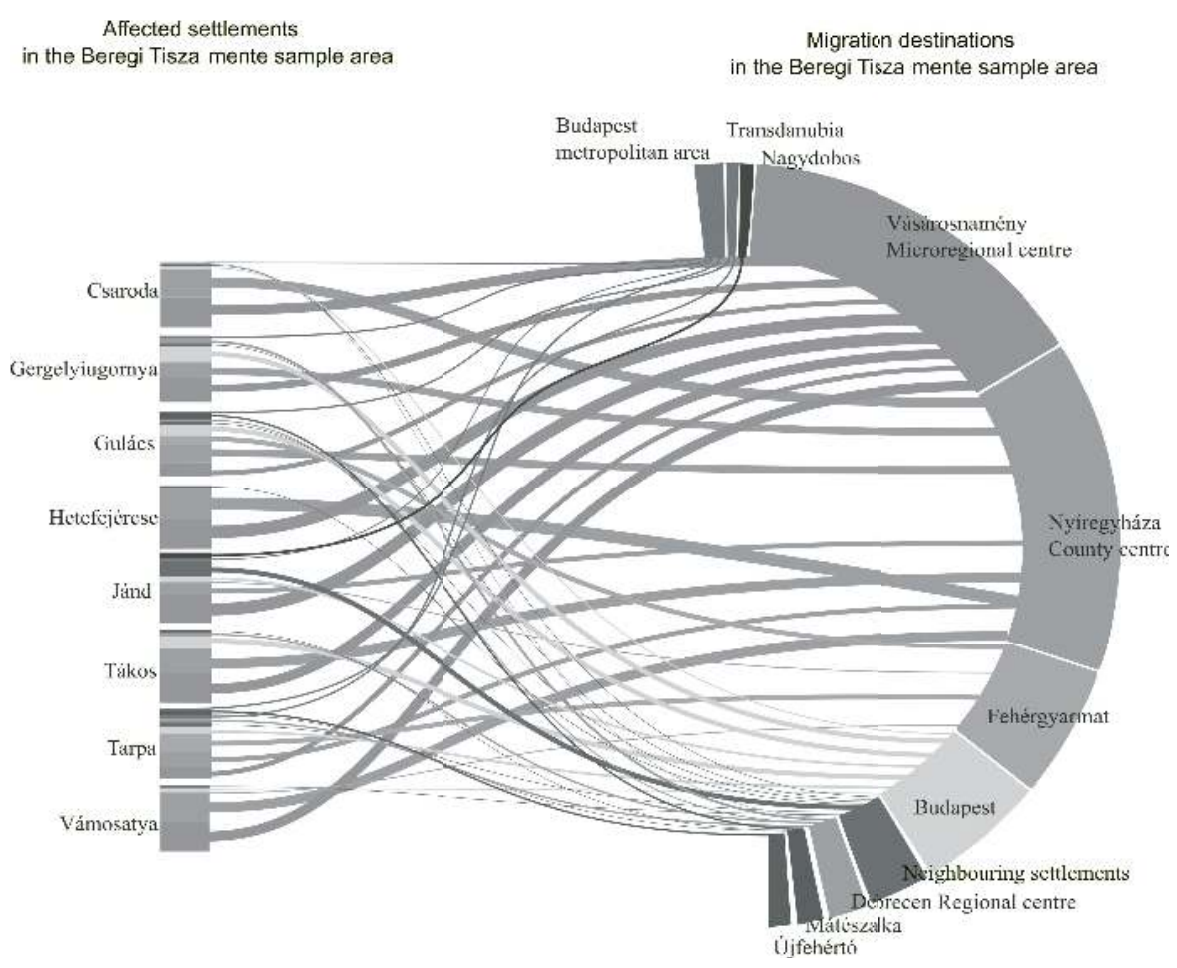

Source: the author, based on survey data, 2021

PIMBY (Gbanie et al. 2013), indicating differences in the perceptions of inequalities and in the recognition of environmental injustice.

\section{Health status and damage caused by environmental injustice}

Early environmental justice studies were strongly linked to health damage caused by environmental harm and disasters. In many cases, this affected minorities, the poor and deprived populations. Our research also explored whether any adverse effects on health have been experienced in the sample areas due to the catastrophes. The analysis first detailed whether statistical data could provide evidence of health damage. Then in each sample area respondents assessed their current health status, compared it to the period before the disaster and were asked to report any health problems. Respondents were also asked if they had a health problem caused directly by the disaster. Statistical data and subjective data from the questionnaire prove that there are significant differences between the affected and non-affected stakeholders in terms of health status. In the case of the red mud spill, $47 \%$ of respondents feel that the majority of the listed symptoms were experienced only after the red mud disaster. The results of the survey were compared with data from the Central Statistical Office (CSO). The distribution of diseases registered by the CSO differed significantly from the results of the survey sample ( $t=4,680 \mathrm{df}=24 \mathrm{sig} 0.001)$. Our sampled population, most of whom were directly affected by the disaster, 
suffered from characteristically different diseases than the rest of the settlement. The damage caused by floods is diverse but most of them can be repaired with sufficient financial resources. However, damage to the environment and injuries in human life are much more difficult to compensate with money, or cannot be compensated at all, whereby achieving justice is very limited. For instance, mental health, which greatly determines physical health, is not in the focus of environmental justice research, even though the shock of a disaster can cause life-defining trauma for many people. As indicated by the literature, the tendency to depression increased significantly after floods in adults (Ahern et al. 2005; Morgan, Ahern, Cairncross 2005; Reacher et al. 2004). Our research also found that mental illnesses, including depression, were particularly high among respondents in the affected regions. On the other hand, higher rates of respiratory diseases were not confirmed by our study; these converged to the national average. Although many respondents feel that environmental injustice causes their illness, this is a subjective perception without medical proof of a link between environmental harm and health status, and.

\section{Discussion}

Since vulnerable areas are delimited by the indicator of exposure to potential environmental injustices and results of the spatial autocorrelation coincide with the inherent spatial structures and relations, they help to understand the process of injustice: the potential areas of environmental injustices are highly affected by environmental risks and are characterized by lower socio-economic status. This result is in line with international literature, pointing out that disadvantaged groups are generally more affected by environmental injustice and they are more exposed to environmental burdens (Braubach 2011; Braubach, Fairburn 2011; Cutter 2006; Laurent 2011; Walker 2012). Processes of environmental injustice are associated with the peripheralization of regions (Enyedi 1996, 2004; Pénzes, Tátrai, Pásztor 2018; Szoboszlai 2006). Environmental justice is a cross-scale problem and our research results indicate that a lower exposure to environmental risks and better socio-economic status on the regional level can also drive local injustices and unjust processes, like in the case of the inland excess water sample areas.

Our research results suggest that local populations are divided on the basis of ethnicity, of being affected by catastrophes and involved in decisionmaking. This shows similar characteristics to the racial injustices typically discovered during the early periods of environmental justice research in America (cf. Bullard 1990, 1994; Cutter 1995; Hamilton 1995; Mohai, Bryant 1992). Research findings also indicate that the time span of the event has a strong influence: the longer the event occurs, the longer it takes for negative feelings and emotions to fade. 
Change in the population and the image of the observed settlements depended largely on the type of compensation given to those affected and the decisions of those who intervened. The observed development of unjust situations is agent-based and depends on individual decisions, which can give room to abuses and unequal opportunities. This is in line with Cutter (1995), Walker (2012) and Williams (1999) who argued that injustice can appear in everyday economic and political decisions besides the legislature. Our results also show that the way residents assess the environmental event after the restoration as fair or unfair depends on the level of compensation and the impact of the event. In the case of the Beregi-Tiszamente study area, due to extensive renovation and compensation, flood events are rather viewed as positive. The attitude towards environmental risks and catastrophe-borne effects highly depends on decision-making mechanisms, and numerous personal or social factors, such as values and norms, principles, formal rules, individual and social knowledge (Gorddard et al. 2016).

With regard to mobility patterns, outmigration is generally a priority for victims of environmental harm, also because the sample areas are located in disadvantaged areas. Although outmigration tends to increase after environmental events, respondents' attitude towards environmental events also depends on their vulnerability (Cutter 2006), financial situation, family ties and personal feelings. Our study also showed that the absence of information results in an increase in dissatisfaction and a decrease in respondents'/stakeholders' ability to make rational decisions.

There is no clear correlation between lower health status and higher environmental risk in the sample areas. This contradicts the results of early environmental justice research which focused on the distributions of environmental burdens and their effects on minorities and disadvantaged groups (Bullard 1990). Nevertheless, our self-assessment survey reveals perceived or real fears of environmental events and these results confirm the increased tendency to depression and anxiety after floods (Ahern et al. 2005; Morgan, Ahern, Cairncross 2005; Reacher et al. 2004).

\section{Summary and concluding remarks}

This paper discussed the post-socialist context of environmental justice research and outlined a selection of environmentally unjust events in Hungary based on 10 years of research. It examined two major forces behind environmental injustices: nature-driven processes - floods, and inland excess water, and their effects - and man-made disasters, such as the red mud spill, and its effects.

Overall, a comparative analysis of the sample areas highlighted similarities and differences between affected areas and indicated that local and state 
interventions play a greater role in Hungary than those bottom-up and grassroots initiatives mentioned in the literature. It is worth noting that these instances of environmental injustice have worsened with the increase in deprivation, marginalization, and polarisation of Hungarian society. Although the size of the area potentially affected by environmental injustice has diminished over the past decade in Hungary, statistical analysis displays the widening of the gap between the best and worst positioned areas, indicating a downward spiralling process of geographical and social polarization of the country. Environmental injustice has more severe consequences for the Roma population and the poor, so special attention must be paid to minority and marginalized groups in the elimination of environmental injustices in Hungary. In general, the method of compensation affects stakeholders' satisfaction and it seems that in Hungary top-down interventions are considered more successful, even though they might feature several unfair and unjust processes. Injustices analysed in this study induced different mobility patterns: wealthier stakeholders can be characterized by 'riskscape', an instant outmigration from the affected area, while the immobility of others was driven by local identity, traditions, family, and fear caused by. Nearby large cities and regional centres can be considered as the main mobility destinations of those who opt out after environmentally harmful events.

The examined cases represent procedural injustice and differences in the recognition of unjust situations. In the case of the Roma population, significant differences can be detected in the 'fear' and 'change' principal components, indicating that cumulating social disadvantages of the Roma population generate a racial accent of environmental injustices. The development of environmental injustice may be negatively influenced by the socioeconomic status and increased vulnerability of the population. The disregard of those in power to make decisions, their lack of knowledge due to the original positions, led in many cases to inadequate responses. The results presented in this paper can help decision-makers to understand the nature of environmental injustice and support them to organize adequate interventional processes during and after future environmental disasters.

\section{Acknowledgement}

This research was funded by the Ministry for Innovation and Technology, Hungary grant number NKFIH-1279-2/2020 and TUDFO/47138-1/2019-ITM. 


\section{References}

Abdullahfed, A. (2017): A Novel Hybrid Method for Measuring the Spatial Autocorrelation of Vehicular Crashes: Combining Moran's Index and Getis-Ord Gi* Statistic. Open Journal of Civil Engineering, 2., 208-221. https://doi.org/10.4236/ojce.2017.72013

Agyeman, J. (2005): Sustainable Communities and the Challenge of Environmental Justice. NYU Press, New York Agyeman, J., Ogneva-Himmelberger, Y. (2009): Environmental Justice and Sustainability in the Former Soviet Union. The MIT Press, Cambridge. https://doi.org/10.7551/mitpress/9780262012669.001.0001

Ahern, M., Kovats, S. R., Wilkinson P., Few, R., Matthies, F. (2005): Global Health Impacts of Floods: Epidemiologic Evidence. Epidemiologic Reviews, 1., 36-46. https://doi.org/10.1093/epirev/mxi004

Alpek, B. L., Tésits, R. (2020): Measuring Regional Differences in Employability in Hungary. Applied Spatial Analysis and Policy, 2., 329-347. https://doi.org/10.1007/s12061-019-09306-6

Beck U. (1992): From Industrial Society to the Risk Society: Questions of Survival, Social Structure and Ecological Enlightenment. Theory, Culture \& Society, 1., 97-123. https://doi.org/10.1177/ 026327692009001006

Been, V. (1994): Locally Undesirable Land Uses in Minority Neighborhoods: Disproportionate Siting or Market Dynamics? The Yale Law Journal, 6., 1383-1422. https://doi.org/10.2307/797089

Begg, C. (2018): Power, responsibility and justice: a review of local stakeholder participation in European flood risk management. Local Environment, 4., 383-397. https://doi.org/10.1080/ 13549839.2017.1422119

Boone, C. G., Fragkias, M., Buckley, G. L., Grove, J. M. (2014): A long view of polluting industry and environmental justice in Baltimore. Cities, 1., 41-49. https://doi.org/10.1016/j.cities.2013.09.004

Boros L., Dudás G., Kovalcsik T. (2020): The effects of COVID-19 on Airbnb. Hungarian Geographical Bulletin, 4., 363-381. https://doi.org/10.15201/hungeobull.69.4.3

Boros L. (2010): A globális gazdaság környezeti és társadalmi konfliktusai. In: Mészáros R., Nagy G., Nagy E., Boros L., Pál V. (szerk.): A globális gazdaság földrajzi dimenziói. Akadémiai Kiadó, Budapest, 276-306.

Boros, L., Nagy, Gy. (2014): The long-term socioeconomic consequences of the Tisza flood of 2001 in Szabolcs-Szatmár-Bereg county, Hungary. Belvedere Meridionale, 4., 122-130. https://doi.org/ 10.14232/belv.2014.4.9

Braubach M. (2011): Environmental health inequailities in Europe. UMID, 2., Themenheft Umweltgerechtigkeit II., 47-51.

Braubach, M., Fairburn, J. (2010): Social inequities in environmental risks associated with housing and residential location - a review of evidence. European Journal of Public Health, 1., 36-42. https://doi.org/10.1093/eurpub/ckp221

Bullard, R. D. (1990): Dumping in Dixie: Race, Class and Environmental Quality. Westview Press, San Francisco

Bullard, R. D. (1994): Unequal Protection: Environmental Justice and Communities of Color. Sierra Club Books, San Francisco

Chukwumerije, D. (2010): Climate justice and the international regime. Wiley Interdisciplinary Reviews Climate Change, 3., 462-474. https://doi.org/10.1002/wcc.52

Clough, E. (2018): Environmental justice and fracking: a review. Current Opinion in Environmental Science \& Health, 3., 14-18. https://doi.org/10.1016/j.coesh.2018.02.005

Cornell, S., Berkhout, F., Tuinstra, W., Tàbara, J. D., Jäger, J., Chabay, I., Wit, B. D., Langlais, R., Mills, D., Moll, P., Otto, I. M., Petersen, A., Pohl, C., Kerkhoff, L. V. (2013): Opening up knowledge systems for better responses to global environmental change. Environmental Science \& Policy, 1., 60-70. https://doi.org/10.1016/j.envsci.2012.11.008

Curran, D. (2013): Risk society and the distribution of bads: Theorizing class in the risk society. British Journal of Sociology, 1., 44-62. https://doi.org/10.1111/1468-4446.12004

Curran, D. (2018): Environmental Justice Meets Risk-Class: The Relational Distribution of Environmental Bads. Antipode, 2., 298-318. https://doi.org/10.1111/anti.12372 
Cutter, S. L. (1995): Race, class and environmental justice. Progress in Human Geography, 1., 111-122. https://doi.org/10.1177/030913259501900111

Cutter, S. L. (2006): Hazards, Vulnerability and Environmental Justice. Earthscan from Routledge, New York

Davidson, P., Anderton, D.L. (2000): Demographics of dumping II: a national environmental equity survey and the distribution of hazardous materials handlers. Demography, 4., 461-466. https:// doi.org/10.1353/dem.2000.0002

Davies, A. R. (2006): Environmental justice as subtext or omission: Examining discourses of antiincineration campaigning in Ireland. Geoforum, 5., 708-724. https://doi.org/10.1016/j.geoforum. 2005.06.005

Eden, S. (2009): Environment. International Encyclopedia of Human Geography, 505-516. https://doi.org/ 10.1016/B978-008044910-4.00268-6

Enyedi Gy. (1996): Regionális folyamatok Magyarországon az átmenet időszakában. Hilscher Rezső Szociálpolitikai Egyesület, Budapest

Enyedi Gy. (2004): Regionális folyamatok a posztszocialista Magyarországon. Magyar Tudomány, 9., 935-941.

EPA (2021): Learn About Environmental Justice. https://www.epa.gov/environmentaljustice/learnabout-environmental-justice (last downloaded 22.11.2021)

Faber, D., McCarthy, D. (2001): The Evolving Structure of the Environmental Justice Movement in the United States: New Models for Democratic Decision-Making. Social Justice Research, 4., 405-421. https://doi.org/10.1023/A:1014602729040

Fabula Sz., Timár J. (2016): A fogyatékosság mint társadalmi-térbeli viszony földrajzi vizsgálata. In: Unger J., Pál-Molnár E. (szerk.): Geoszférák 2015: A Szegedi Tudományegyetem Földtudományok Doktori Iskolájának eredményei. SZTE TTIK Földrajzi és Földtani Tanszékcsoport, Szeged, 89-111.

Filčák, R. (2007): Environmental Justice in the Slovak Republic. The case of the roma ethnic minority. Unpublished doctoral dissertation. Central European University, Budapest

Fodor I. (1987): KGST együttmúködés a környezetvédelem társadalomtudományi kutatásaiban. Tér és Társadalom, 2., 106-112. https://doi.org/10.17649/TET.1.2.24

Gbanie, S. P., Tengbe, P. B., Momoh, J. S., Medo, J., Kabba, V. T. S. (2013): Modelling landfill location using Geographic Information Systems (GIS) and Multi-Criteria Decision Analysis (MCDA): Case study Bo, Southern Sierra Leone. Applied Geography, 1., 3-12. https://doi.org/10.1016/ j.apgeog.2012.06.013

Gorddard, R., Colloff, M. J., Wise, R. M., Ware, D., Dunlop, M. (2016): Values, rules and knowledge: Adaptation as change in the decision context. Environmental Science \& Policy, 1., 60-69. https:// doi.org/10.1016/j.envsci.2015.12.004

Gyuris, F. (2017): Urban inequality: Approaches and narratives. In: Gerhard, U., Hoelscher, M., Wilson, D. (eds.): Inequalities in Creative Cities. Palgrave Macmillan, New York, 41-76.

Haining, R. P. (2001): Spatial Autocorrelation. International Encyclopedia of the Social \& Behavioral Sciences, 14763-14768.

Hajdú Z. (2006): A szocialista természetátalakítás kérdései Magyarországon, 1948-1956. In: Kiss A., Mezősi G., Sümeghy Z. (szerk.): Táj, környezet és társadalom. Ünnepi tanulmányok Keveiné Bárány Ilona professzor asszony tiszteletére. SZTE Éghajlattani és Tájföldrajzi, Természetföldrajzi és Geoinformatikai Tanszék, Szeged, 245-258.

Hajdú Z., Rácz Sz. (2020): Államhatár-politikák az Európai Unióban és Magyarországon a globális koronavírus-válság kezdeti időszakában. Tér és Társadalom, 2., 202-210. https://doi.org/ 10.17649/TET.34.2.3260

Hamilton, J. T. (1995): Testing for Environmental Racism: Prejudice, Profits, Political Power? Journal of Policy Analysis and Management, 1., 107-132. https://doi.org/10.2307/3325435

Harper, K., Steger, T., Filčák, R. (2009): Environmental Justice and Roma Communities in Central and Eastern Europe. Environmental Policy and Governance, 4., 251-268. https://doi.org/10.1002/eet.511

Higgs, G., Langford, M. (2009): GIScience, environmental justice, \& estimating populations at risk: The case of landfills in Wales. Applied Geography, 1., 63-76. https://doi.org/10.1016/j.apgeog. 2008.07.006 
Kaya, I. A., Erol, N. K. (2016): Conflicts over Locally Unwanted Land Uses (LULUs): Reasons and solutions for case studies in Izmir (Turkey). Land Use Policy, 1., 83-94. https://doi.org/10.1016/ j.landusepol.2016.07.011

Kolosi T., Keller T. (2010): Kikristályosodó társadalomszerkezet. In: Kolosi T., Tóth I. Gy. (szerk.): Társadalmi Riport 2010. Tárki, Budapest, 105-138.

Kovalcsik, T., Nzimande, N. P. (2019): Theories of the voting behaviour in the context of electoral and urban geography. Belvedere Meridionale, 4., 207-220. https://doi.org/10.14232/belv.2019.4.15

Kovács, S. Zs., Koós, B., Uzzoli, A., Páger, B., Egyed, I., (2020): Regional effects of the COVID-19 pandemic and policy responses in Hungary. R-Economy, 3., 208-221. https://doi.org/10.15826/ recon.2020.6.3.018

Kurtz, H. E (2003): Scale frames and counter-scale frames: constructing the problem of environmental injustice. Political Geography, 8., 887-916. https://doi.org/10.1016/j.polgeo.2003.09.001

Laurent, É. (2011): Issues in environmental justice within the European Union Ecological Economics, 11., 1846-1853. https://doi.org/10.1016/j.ecolecon.2011.06.025

Liao, K. H, Hui Chan, J. K., Huang, Y. L. (2019): Environmental justice and flood prevention: The moral cost of floodwater redistribution, Landscape and Urban Planning, 189. 36-45. https:// doi.org/10.1016/j.landurbplan.2019.04.012

Maantay, J., Maroko, A. (2009): Mapping Urban Risk: Flood Hazards, Race, \& Environmental Justice in New York. Applied Geography, 1., 111-124. https://doi.org/10.1016/j.apgeog.2008.08.002

Málovics Gy. (2012): Környezetvédelem vagy társadalmi igazságosság? A környezeti igazságosság koncepciójának értelmezési lehetőségei és hazai jelentősége. Kovász, 1-4., 3-31.

Máté É., Pirisi G., Trócsányi A. (2017): A felszakadozó térszerkezet Magyarországa - Esettanulmány a Dél-dunántúli régióból. In: Benő A., Gúti E., Juhász D., Szoták Sz., Terbe E., Trócsányi A. (szerk.): Tudományköziség és magyarságtudomány a nyelvi dimenziók tükrében: A VIII. Nemzetközi Hungarológiai Kongresszus (Pécs, 2016) három szimpóziumának elöadásai. Termini Egyesület, Törökbálint, 196-205.

Mitchell, G., Norman, P. D. (2012): Longitudinal environmental justice analysis: Co-evolution of environmental quality and deprivation in England, 1960-2007. Geoforum, 1., 44-57. https:// doi.org/10.1016/j.geoforum.2011.08.005

Mohai, P., Bryant, B. (1992): Environmental Racism: Reviewing the Evidence. In: Bryant, B., Mohai, P. (eds.): Race and the Incidence of Environmental Hazards. Westview Press, Boulder, CO, 163-176. https://doi.org/10.4324/9780429303661-13

Morar, C., Lukić, T., Basarin, B., Valjarević, A., Vujičić, M., Niemets, L., Telebienieva, I., Boros, L., Nagy, Gy. (2021): Shaping Sustainable Urban Environments by Addressing the Hydro-Meteorological Factors in Landslide Occurrence: Ciuperca Hill (Oradea, Romania). International Journal of Environmental Research and Public Health, 9., 5022. https://doi.org/10.3390/ijerph18095022

Morgan, O., Ahern, M., Cairncross, S. (2005): Revisiting the Tsunami: Health Consequences of Flooding. PLoS Medicine, 6., e 184. https://doi.org/10.1371/journal.pmed.0020184

Nagy E., Timár J., Nagy G., Velkey G. (2015): A társadalmi-térbeli marginalizáció folyamatai a leszakadó vidéki térségekben. Tér és Társadalom, 1., 35-52. https://doi.org/10.17649/TET.29.1.2680

Nagy G. (2006): A gazdasági fejlettség minőségi indikátorai. In: Kanalas I. Kiss A. (szerk.): A perifériaképződés típusai és megjelenési formái Magyarországon. MTA RKK Alföldi Tudományos Intézet, Kecskemét, 86-97.

Nagy Gy., Boros L. (2015): A környezeti igazságtalanságok feltárásának térinformatikai módszerei In: Boda J. (szerk.): Az elmélet és a gyakorlat találkozása a térinformatikában: VI. Térinfomatikai Konferencia és Szakkiállitás. Debreceni Egyetemi Kiadó, Debrecen, 293-306.

Nagy, Gy., Papp, S., Miklós, B. (2017): Environmental Injustices in Border Regions: Case Study of Water Quality and Inland Excess Water. In: Toca, C. V., Horga, I., Soproni, L. (eds.): The evaluation of cross-border cooperation. Debrecen University Press, Oradea University Press, 57-70.

Nagy, Gy., Vida, Gy., Boros, L., Ćirić, D. (2019): Decision trees in environmental justice research - a case study on the floods of 2001 and 2010 in Hungary. Open Geosciences, 1., 1025-1034. https:// doi.org/10.1515/geo-2019-0079

Newton, D. E. (2009): Environmental Justice. ABC Clio, Oxford 
Okereke, C. (2006): Global environmental sustainability: International equity and conceptions of justice in multilateral environmental regimes. Geoforum, 5., 725-738. https://doi.org/10.1016/ j.geoforum.2005.10.005

Oskarsson, P., Bedi, B. P. (2018): Extracting environmental justice: Countering technical renditions of pollution in India's coal industry. The Extractive Industries and Society, 3., 340-347. https:// doi.org/10.1016/j.exis.2018.05.003

Pál, V., Boros, L. (2010): The relationship between health policy and spatial justice - the case of Hungary. Megatrend Review, 1., 249-264.

Pál, V., Lados, G., Ilcsikné Makra, Zs., Boros, L., Uzzoli, A., Fabula, Sz. (2021): Concentration and inequality in the geographic distribution of physicians in the European Union, 2006-2018. Regional Statistics, 3., 3-28. https://doi.org/10.15196/RS110308

Pelletier, N. (2010): Environmental sustainability as the first principle of distributive justice: Towards a communitarian-based normative foundation for ecological economics. Ecological Economics, 10., 1887-1894. https://doi.org/10.1016/j.ecolecon.2010.04.001

Pénzes J. (2014): Periférikus térségek lehatárolása-Dilemmákés lehetőségek. Didakt Kft., Debrecen

Pénzes J., Tátrai P., Pásztor I. Z. (2018): A roma népesség területi megoszlásának változása Magyarországon az elmúlt évtizedekben. Területi Statisztika, 1., 3-26. https://doi.org/10.15196/ TS580101

Pirisi G. (2019): A reziliencia lehetséges értelmezése a településföldrajzi kutatásokban. Tér és Társadalom, 2., 62-88. https://doi.org/10.17649/TET.33.2.3080

Prugberger, T. (2001): A globalizáció és a környezetvédelem neuralgikus kérdései a jogalkotás és a jogalkalmazás síkján. Magyar Közigazgatás, 10., 619-625.

Rabóczky L., Pomázi I., Zsikla Gy. (1990): A környezet és a gazdaság kapcsolatának néhány kérdése (Problémák, feladatok, megoldási lehetőségek). Földrajzi Értesíto", 1-4., 177-189.

Rawls, J. (1971): A Theory of Justice. Harvard University Press, Cambridge

Reacher, M., McKenzie, K., Lane, C., Nichols, T., Kedge, I., Iversen, A., Hepple, P., Walter, T., Laxtion, C., Simpson, J., Lewes Flood Action Recovery Team (2004): Health impacts of flooding in Lewes: a comparison of reported gastroinestinal and other illness and mental healt in flooded and non-flooded households. Communicable Disease and Public Health, 1., 39-46.

Sachs, W. (2008): Ökológia és emberi jogok. Kovász, 3-4., 15-56.

Soja, E. W. (2010): Seeking Spatial Justice. University of Minnesota Press, Minneapolis. https://doi.org/ 10.5749/minnesota/9780816666676.001.0001

Špirić, J. (2018): Ecological distribution conflicts and sustainability: lessons from the post-socialist European semi-periphery. Sustainability Science, 3., 661-676. https://doi.org/10.1007/s11625017-0505-6

Steger, T. (ed.) 2007: Making the case for environmental justice in Europe. CEU Center for Environmental Policy and Law (CEPL), Health and Environment Alliance (HEAL), Coalition for Environmental Justice, Budapest

Steiger K. (1997): Bevezetés a filozófiába. Holnap Kiadó, Budapest

Swift, A., Liu, L., Uber, J. (2008): Reducing MAUP bias of correlation statistics between water quality and GI illness. Computers, Environment and Urban Systems, 32., 134-148. https://doi.org/10.1016/ j.compenvurbsys.2008.01.002

Szoboszlai Zs. (2006): Szegénység - marginalizáció - szegregáció. In: Kanalas I., Kiss A. (szerk.): A perifériaképződés típusai és megjelenési formái Magyarországon. MTA RKK Alföldi Tudományos Intézet, Kecskemét, 116-134.

Uzzoli, A., Egri, Z., Szilágyi, D., Pál, V. (2020): Does better availability mean better accessibility? Spatial inequalities in the care of acute myocardial infarction in Hungary. Hungarian Geographical Bulletin, 4., 401-418. https://doi.org/10.15201/hungeobull.69.4.5

Váradi M. M. (2014): Szegénység és projektvilág. In: Nagy E., Nagy G. (szerk.): Polarizáció - függőség - krízis: Eltérő térbeli válaszok. MTA KRTK RKI Alföldi Tudományos Osztály, Békéscsaba, 10-17.

Varga, Cs., Kiss, I., Ember, I. (2002): The Lack of Environmental Justice in Central and Eastern Europe. Environmental Health Perspectives, 11., A662-A663. https://doi.org/10.1289/ehp.110-a662 
Walker, G. (2012): Environmental Justice: Concepts, Evidence and Politics. Routledge, London

Walker, G., Burningham, K., Fielding, J., Smith, G., Thrush, D., Fay, H. (2006): Addressing Environmental Inequalities: Flood Risk. Science Report, Environment Agency, Bristol

Williams, R. W. (1999): Environmental injustice in America and its politics of scale. Political Geography, 1., 49-73. https://doi.org/10.1016/S0962-6298(98)00076-6 